\author{
Dariusz Pabiś \\ WSD Redemptorystów w Tuchowie \\ ORCID: 0000-0002-5099-5419
}

\begin{abstract}
Andrzej Makowski
WSD Redemptorystów w Tuchowie, WSD Zakonu Paulinów w Krakowie

ORCID: 0000-0003-2647-3124

\section{Integralny System Nowej Ewangelizacji jako odpowiedź na wezwanie Kościoła w Ameryce Łacińskiej do nowej ewangelizacji}

\begin{abstract}
Abstrakt: Od czasu Soboru Watykańskiego Il świadomość ewangelizacyjnych wyzwań, przed jakimi stoi Kościół, jest coraz mocniejsza. Przynaglenie, aby w szybko zmieniającej się rzeczywistości poszukiwać dla ewangelizacji świeżych form i metod, zaczęło być określane - począwszy od III Konferencji Rady Biskupów Ameryki Łacińskiej (CELAM) w Puebla z roku 1979 - jako „nowa ewangelizacja”. Zaś dzięki św. Janowi Pawłowi II określenie to na stałe zagościło w świadomości Kościoła powszechnego.

Pontyfikat papieża Franciszka sprzyja, aby Ameryka Łacińska nadal kontynuowała inspirującą rolę wobec całego Kościoła w obszarze "nowej ewangelizacji”. W przekonaniu autorów artykułu godnym uwagi jest Integralny System Nowej Ewangelizacji (SINE - Sistema Integral de la Nueva Evangelización) - zainicjowany w Meksyku i z powodzeniem implementowany w wielu regionach świata, gdzie stał się oficjalnym programem duszpasterskim dla licznych diecezji i parafii. Wobec dostrzegania realiów Kościoła w Polsce i ewangeliczny niepokój wielu duszpasterzy, SINE jest ciekawą propozycją, która - twórczo rozwinięta - może przekształcić tradycyjnie prowadzoną parafię w tętniącą życiem wspólnotę wspólnot.
\end{abstract}

Słowa klucze: Integralny System Nowej Ewangelizacji, model pastoralny, nowa ewangelizacja, parafia, SINE

\footnotetext{
Głoszenie Ewangelii jest pierwszorzędnym zadaniem Kościoła. Yodejmuje on je w duchu odpowiedzialności za kontynuowanie misji zleconej mu przez Chrystusa. Od czasu Soboru Watykańskiego II świadomość jej znaczenia coraz silniej dojrzewa zwłaszcza
} 
w kontekście pojawiających się coraz to nowych wyzwań, jakie współczesny świat stawia przed Kościołem. Wyjątkowo wyraźnie jest to widoczne w Ameryce Łacińskiej. Nie może zatem dziwić, że przynaglenie do misyjnej aktywności jest tam szczególnie naglące. Zostało ono po raz pierwszy sformułowane podczas III Konferencji Rady Biskupów Ameryki Łacińskiej (CELAM) w Puebla w roku 1979 jako wezwanie do nowej ewangelizacji. Dzięki kolejnym konferencjom - w Santo Domingo i Aparecidzie - nabrała ona na tym kontynencie szczególnego dynamizmu. Jan Paweł II wskazał natomiast na jej znaczenie w perspektywie globalnej.

Jedną z wielu ważnych form twórczej i - jak pokazuje doświadczenie - owocnej odpowiedzi na wezwanie do podjęcia dzieła nowej ewangelizacji jest zainicjowany w Meksyku Integralny System Nowej Ewangelizacji (Sistema Integral de la Nueva Evangelización - SINE). W ciągu ostatnich dziesięcioleci zdobył on uznanie zarówno duchownych, jak i świeckich nie tylko w Ameryce Łacińskiej. Jest oficjalnym programem duszpasterskim dla wielu diecezji i parafii. Stał się bowiem impulsem, który tradycyjnym parafialnym strukturom nadaje misyjny dynamizm i z czasem przekształca je w żywą wspólnotę, nieustannie ewangelizującą i ewangelizowaną. Przypadająca w tym roku czterdziesta rocznica konferencji CELAM w Puebla stanowiła dla autorów szczególną okazję do podjęcia tego tematu i zaprezentowania go polskiemu czytelnikowi.

\section{Kościół wobec nowej ewangelizacji}

\subsection{Wyzwania Kościoła soborowego}

Sobór Watykański II był szczególną okazją, aby mogły wybrzmieć dwa znaczące zagadnienia: Kościół i świat, które wzajemnie na siebie oddziałują. Można stwierdzić, że Lumen gentium i Gaudium et spes - dwie wielkie soborowe konstytucje - dały tym dwóm tematom formę i treść. Mówiąc o Kościele i świecie, nieuprawnione byłoby twierdzić, że są to nieprzystające do siebie rzeczywistości. Pozostają one ze sobą w bliskiej relacji, która ma charakter dialektycznego 
napięcia. Są różne, ale wzajemnie się zakładają ${ }^{1}$. Sobór dostrzegł centralne miejsce ludu Bożego w wędrówce pośród narodów, ludu odkupionego drogocenną krwią Chrystusa, napełnionego Duchem prawdy i świętości i posłanego do wszystkich ludzi jako światłość dla świata oraz sól ziemi. W ten sposób została zdefiniowana tożsamość Kościoła. Jest on zbudowany na fundamencie Chrystusa i Jego Ducha, a jednocześnie odważnie wychodzi naprzeciw wszelkim sytuacjom kulturowym, społecznym i antropologicznym². „Radość i nadzieja, smutek i lęk ludzi w naszych czasach, szczególnie ubogich i wszelkich uciśnionych, są również radością i nadzieją, smutkiem i lękiem uczniów Chrystusa"3. Deklaracja ta jest owocem długiego procesu dojrzewania Kościoła do wejścia na drogę twórczego dialogu ze światem. Podjęcie go było nie tylko kwestią sprawiedliwości, ale stanowiło wypełnienie zamysłu samego Chrystusa ${ }^{4}$.

Wysiłki zmierzające ku otwartości w perspektywie dialogu ze światem stanowiły dominantę zmian w latach 1965-1975. Nie zawsze jednak generowało to pozytywne efekty. Powstawały obszary doktrynalnego i duszpasterskiego zamieszania, z racji całego szeregu konfliktów, które rodziła stanowcza reakcja obrońców przedsoborowych form myślenia i działania na aktywność tych, co - odwołując się do soboru - rozmywali nią chrześcijaństwo i kościelną tożsamość. Ten pierwszy etap był w dużej mierze naznaczony atomizacją duszpasterstwa. Wielu było niezdolnych do docenienia duszpasterskich form zaangażowania tych, którzy myśleli inaczej i pracowali w innych kontekstach społeczno-politycznych. Tak rozwijająca się sytuacja sprzyjała do podjęcia na nowo szczerej i syntetyzującej całość refleksji ${ }^{5}$.

Por. T. Kelly, When the Gospel, 51-52; A. Quarracino, „El Concilio, Medellín, Puebla", 36.

2 Por. Lumen gentium, 9; Kongregacja ds. Instytutów Życia Konsekrowanego i Stowarzyszeń Życia Apostolskiego, Rozpoznawajcie. Do osób konsekrowanych, 21.

Gaudium et spes, 1.

4 Por. C. Leal, „La noción de justicia”, 184-185.

5 Por. Equipo de Reflexión Teológica Pastoral de CELAM, Reflexión sobre Puebla, 28. 


\subsection{Konferencja w Puebla i nowa ewangelizacja}

Na przełomie stycznia i lutego 1979 roku w meksykańskim mieście Puebla odbyła się III Generalna Konferencja CELAM. Była ona dla Kościoła w Ameryce Łacińskiej swego rodzaju zwieńczeniem długiego i pełnego trudności okresu refleksji i sporów wokół zasadniczych procesów natury religijnej, moralnej i społecznej, zapoczątkowanego przez Sobór Watykański II. Jej hasło brzmiało: „Ewangelizacja w teraźniejszości i przyszłości Ameryki Łacińskiej”6. Jest ono w pełni zrozumiałe w perspektywie propozycji, która wybrzmiała w inauguracyjnym wystąpieniu Jana Pawła II, aby adhortacja apostolska Pawła VI Evangelii nuntiandi stała się dla uczestników konferencji punktem odniesienia i tłem wszelkich rozważań ${ }^{7}$. Historyczność adhortacji polega nie tylko na tym, że pozwala ona pełniej zrozumieć konferencję w Puebla, ale i na tym, że wyznacza początek i niejako opisuje nowy etap posoborowej dynamiki, która karmi się wskazaną w konstytucji dogmatycznej o Kościele wizją ludu Bożego, podejmującego ewangelizację w duchu odpowiedzialności za kontynuowanie otrzymanej od Chrystusa zbawczej misji. Ewangelizacja jest punktem odniesienia dla działań duszpasterskich Kościoła i wszelkiego podejmowanego przezeń dialogu ze światem ${ }^{8}$. Paweł VI w adhortacji stwierdza, że „nakaz głoszenia Ewangelii wszystkim ludziom jest pierwszorzędnym i naturalnym posłannictwem Kościoła; nakaz ten i posłannictwo zobowiązuje tym bardziej w dobie poważnych przemian w dzisiejszym społeczeństwie" ". Jeszcze bardziej aktualnie brzmiało to w kontekście Ameryki Łacińskiej. Ewangelizacja stawała się istotną częścią samoświadomości Kościoła na tym kontynencie, co nie mogło pozostać bez wpływu na jego aktywność w przestrzeni duszpasterskiej. Oznaczało to zakończenie pewnej epoki, w której chrześcijańskość czy katolickość kontynentu wydawały się oczywistością, a wysiłki duszpasterskie mogły się

6 Por. J. Jiménez Carvajal, „Las cuatro conferencias”, 179; G. Marchesi, „Puebla y la teología”, 271; A. Quarracino, „El Concilio”, 43-44.

7 Por. Jan Paweł II, „Discurso en la inauguración”, 60.

8 Por. C.M. Galli, „Dones de la Iglesia”, 598.

9 Paweł VI, Evangelii nuntiandi, 14. 
ograniczać jedynie do sfery kultu religijnego, administrowania sakramentów czy pouczeń natury moralnej ${ }^{10}$.

Ewangelizacja niesie ze sobą nowość, ponieważ komunikuje Chrystusa, Nowego Człowieka (por. Ef 2,15), który wszystko czyni nowym (por. Ap 21,5) i przynosi nowy świat królestwa Bożego. Ewangelizacja oznacza również, że nowość Dobrej Nowiny domaga się nowych form jej głoszenia. Potrzebuje ona ciągłej odnowy w związku z jej głosicielami i odbiorcami. Oznacza ona nowość, ponieważ głosiciel staje się jednocześnie jej odbiorcą ${ }^{11}$, a odbiorca w sposób naturalny zaczyna być głosicielem ${ }^{12}$. Potrzeba nowości jest również związana z zawartością przepowiadania oraz z metodami służącymi komunikacji Dobrej Nowiny - środkami i sposobami ${ }^{13}$. Jeśli mamy na uwadze te stwierdzenia z Evangelii nuntiandi, będące echem szóstego punktu soborowego dekretu o misyjnej działalności Kościoła, staje się zrozumiałe pojawianie się w tekście III Konferencji z Puebla określenia „nowa ewangelizacja”. W punkcie 366 dokumentu z Puebla czytamy: „Nowymi sytuacjami mającymi swoje źródło w zmianach społeczno-kulturalnych i domagającymi się nowej ewangelizacji są: emigracja do innych krajów, wielkie aglomeracje miejskie, rzesze ludzi ze wszystkich warstw społecznych dotknięte kryzysem wiary, grupy wystawione na działanie sekt i ideologii, które nie szanują tożsamości, wprowadzają zamieszanie i prowokują podziały"14. W podobnym duchu poruszono w punkcie 433 dokumentu z Puebla zagadnienie ewangelizacji w odniesieniu do wielkich miast, a w punkcie 436 w odniesieniu do zjawiska sekularyzacji, które staje się wyzwaniem dla wiary i pobożności ludowej ${ }^{15}$. Nie ma zatem wątpliwości, że kolebką określenia „nowa ewangelizacja” jest Ameryka Łacińska, a początek pogłębionej refleksji nad jej znaczeniem należy łączyć

10 Por. P. Andrade Ponte, „La catequesis latinoamericana”, 136.

11 Por. Paweł VI, Evangelii nuntiandi, 15.

12 Por. tamże, 24.

13 Por. tamże, 25, 29, 40, 80. Por. C.M. Galli, „Dones de la Iglesia”, 599.

14 Conferencia Episcopal Latinoamericana, ,Documento final [Puebla]”, 366; por. C.M. Galli, „Dones de la Iglesia”, 602.

15 Por. C.M. Galli, „Dones de la Iglesia”, 602. 
właśnie z III Konferencją CELAM ${ }^{16}$, której dokument końcowy został zatwierdzony przez Jana Pawła II 23 marca 1979 roku. Papież przy okazji jego promulgacji stwierdził, że tekst ten jest kamieniem milowym w realizacji misji ewangelizacyjnej Kościoła. Dwa i pół miesiąca później zainspirowany konkluzjami z Puebla użył pojęcia „nowa ewangelizacja” w czasie swojej pierwszej wizyty w Polsce, w Nowej Hucie ${ }^{17}$.

\subsection{Nowa ewangelizacja w nauczaniu CELAM}

Jan Paweł II pojęcie „nowa ewangelizacja” uczynił hasłem przewodnim swojej pasterskiej posługi. Formę planu pastoralnego przybiera ona w przemówieniu papieża do biskupów zgromadzonych na IX Zgromadzeniu Plenarnym CELAM, które wygłosił w katedrze Port-au-Prince na Haiti 9 marca 1983 roku. Skierował do nich apel o zaangażowanie się w nową ewangelizację, ale - jak sprecyzował - nie powtórną, lecz nową w swym zapale, metodach i wyrazie ${ }^{18}$. Papież wyjaśnił, że nowa ewangelizacja nie jest jedynie tematem rozważań teologicznych czy pastoralnych. Powinna ona być przede wszystkim organicznym planem duszpasterskim nie tylko dla Kościoła w Ameryce Łacińskiej. Wyzwania, przed jakimi on stoi, są bowiem natury globalnej ${ }^{19}$.

W październiku 1992 roku w Santo Domingo odbyła się IV Konferencja CELAM, której myśl przewodnia brzmiała: „Nowa ewangelizacja, promocja ludzka, chrześcijańska kultura”. Zarówno okazja, jak i samo miejsce konferencji wskazywały na chęć celebracji rocznicy 500 lat ewangelizacji kontynentu latynoamerykańskiego i były zachętą do energicznego podjęcia nowej ewangelizacji. Pierwszy akcent zostały położony na osobie i przesłaniu Chrystusa. Ewangelizować oznacza głosić Chrystusa. W Nim jest bowiem cała prawda zbawcza i uzdrawiająca moc, jaką Kościół ma od zawsze do przekazania

16 Por. R. Fisichella, La nuova evangelizzazione, 21; J.O. Ruiz Arenas, „Dokument z Aparecidy”; A. Peterson, M. Vasquez, „New Evangelization”, 315.

17 Por. C.M. Galli, ,Dones de la Iglesia”, 602.

18 Por. Jan Paweł II, Ecclesia in America, nr. 6; Jan Paweł II, „Przemówienie do Konferencji Episkopatów Ameryki Łacińskiej (CELAM)”, 28-30.

19 Por. A. Gonzales Dorado, „La Nueva Evangelización”, 36. 
światu. Tylko ona może rozświetlić tajemnicę ludzkiego istnienia oraz ukazać możliwość spełnienia wszystkich najgłębszych pragnień człowieka. Z tego względu Kościół potrzebuje zawsze nowego zapału, sił i zdolności do ewangelizacji. Potrzeba mu w tym względzie również nowych metod i nowych form wyrazu ${ }^{20}$.

Milowym krokiem w rozumieniu pojęcia nowej ewangelizacji była V Konferencja CELAM w Aparecidzie z 2007 roku. Procesy społeczne, takie jak gwałtowna sekularyzacja, masowe odchodzenie katolików do sekt i Kościołów protestanckich, marazm oraz bierność kościelnych struktur, nieskuteczność statycznego duszpasterstwa, domagały się szybkiej zmiany myślenia o Kościele. Dokument z Aparecidy wskazuje cztery filary duszpasterskiego działania, którymi są: formacja uczniów Chrystusa; powołanie misyjne, które jest zadaniem wszystkich Jego uczniów, w tym świeckich; budowanie wspólnoty z uwzględnieniem ubogich oraz życie godne i szczęśliwe w Jezusie Chrystusie. To wszystko może się dokonać poprzez „nawrócenie duszpasterskie", proponowane również przez ten dokument. Dotyczy ono wspólnot chrześcijańskich i polega na przejściu od zabiegów duszpasterskich o charakterze konserwującym (zachowawczym) do działań o charakterze misyjnym. Wspólnoty mają poszukiwać ludzi, którzy są ochrzczeni, ale których nie ma w kościołach. Potrzebny jest do tego nowy język i nowy styl duszpasterstwa ${ }^{21}$.

\section{SINE - skonkretyzowana forma urzeczywistniania nowej ewangelizacji}

\subsection{SINE wobec kryteriów nakazu misyjnego Chrystusa}

W Orędziu XIII Zgromadzenia Ogólnego Synodu poświęconego nowej ewangelizacji czytamy, że nie chodzi w niej „o wynajdowanie nie wiadomo jakich nowych strategii, [...] ale trzeba na nowo odkryć sposoby, w jakie w dziejach Jezusa ludzie zbliżali się do Niego i przez

20 Por Conferencia Episcopal Latinoamericana, "Documento final [Santo Domingo]", 6-12; R. Hajduk, Ewangelia na forum świata, 205.

${ }^{21}$ Por. M. Fernández, K. Kaproń, „Nie możemy biernie czekać”, 67-72. 
Niego byli powoływani, aby te same sposoby zastosować w warunkach naszych czasów"22.

Ewangelizacja powinna być programem dla wszystkich, ponieważ jest ona osią, wokół której realizuje się cała aktywność Kościoła, fundamentem, od którego zależy jego żywotność, wreszcie bazą, na której można nabudowywać kolejne elementy składające się na szeroko rozumiane duszpasterstwo ${ }^{23}$.

W żywej Tradycji Kościoła zawarte są kryteria pozwalające rozpoznać, które z dzieł określanych jako ewangelizacyjne są zgodne z nakazem misyjnym Chrystusa. W tym procesie rozeznania należy zwrócić uwagę na zachowanie komunii eklezjalnej, wierności Magisterium Kościoła, głoszenie słowa Bożego z radością i odwagą, gwarancję ciągłego dynamizmu misyjnego, zdolność do budowania wspólnoty i dzielenia się owocami wiary i miłości, szczególnie z ubogimi. Są to elementy, które dają pewność co do prawdziwości natchnienia Bożego ${ }^{24}$. Wszystkie te kryteria spełnia coraz bardziej rozpoznawalny - już nie tylko w Ameryce Łacińskiej, ale również w innych regionach świata - Integralny System Nowej Ewangelizacji (SINE). Metropolita stolicy Meksyku i uczestnik III Konferencji CELAM w Puebla kard. Ernesto Corripio Ahumada w roku 1992 stwierdził, że SINE wydał obfite owoce zarówno na płaszczyźnie wspólnoty eklezjalnej, jak i odnowy misyjnej. Podkreślił, że zmienia on parafie pracujące według jego założeń w sposób zorganizowany i systematyczny w mocne ośrodki misyjne, a rozprzestrzeniając się na inne parafie i diecezje w wielu krajach (w roku 1992 było to już 600 parafii w 100 diecezjach 13 krajów na świecie), ma znaczący wpływ na powstrzymywanie i neutralizowanie działalności wielu protestanckich grup i sekt ${ }^{25}$. W podobnym duchu wypowiedział się Rino Fisichella z Papieskiej Rady ds. Promocji Nowej Ewangelizacji, który w piśmie z 1 kwietnia 2014 roku (Prot. N.NE/363/2014/P) stwierdził, że SINE jest inicjatywą właściwą dla dzieła nowej ewangelizacji oraz

22 Synod Biskupów, XIII Zwyczajne Zgromadzenie Ogólne, Orędzie do Ludu Bożego, 4.

23 Por. A. Navarro, Parroquia evangelizadora, 35.

24 Por. R. Fisichella, „Carta al Equipo”.

25 Por. Sentido eclesial en el origen del SINE. 
częścią szerokiej i wielowymiarowej propozycji doświadczeń na polu ewangelizacji, którymi Bóg błogosławi swój Kościół. Wyraził on również nadzieję, że system stanie się ważną częścią wysiłków duszpasterskich Kościoła, szczególnie latynoamerykańskiego ${ }^{26}$.

\subsection{Początki SINE}

W roku 1973 w Meksyku, stolicy kraju o tej samej nazwie, powstał ośrodek, którego celem była ewangelizacja i katechizacja. Nosił on nazwę Centrum Formacji dla Posługujących (Centro de Formación de Servidores). Działalność podstawowa polegała na oferowanej zarówno dorosłym, jak i młodzieży ewangelizacji i katechezie poprzez organizowanie rekolekcji i seminariów. Chodziło o zaproponowanie wszystkim chętnym możliwości inicjacji chrześcijańskiej i odnowy wiary. Od samego początku było oczywiste, że jest to proces o kapitalnym znaczeniu dla każdego, kto poważnie traktuje wymagania życia chrześcijańskiego. Obejmował on zatem dwa ważne elementy:

a. ewangelizację - przepowiadanie kerygmatu, stwarzające możliwość doświadczenia osobistego spotkania z Chrystusem i otwierające serce na dar wiary, oraz

b. katechezę, która przyczynia się do pogłębienia i dojrzewania tej wiary. Przez Centrum przewijało się każdorazowo kilka tysięcy osób uczestniczących w seminariach ewangelizacyjnych i katechezie trwającej w cyklach po pięć lat i rozłożonej na dziesięć poziomów $^{27}$.

W roku 1981 Francisco M. Aguilera González, biskup VI wikariatu archidiecezji miasta Meksyk, powierzył grupie osób tworzących Centrum obszerne terytorium zamieszkałe przez ubogich mieszkańców wikariatu, aby zrealizować tam projekt Parafii jako Wspólnoty Ewangelizacyjnej. Chodziło o nadanie wysiłkom podejmowanym przez Centrum zorganizowanej formy w ramach struktur diecezjalnych. Pierwszą misję ewangelizacyjną rozpoczęto, idąc „od drzwi do drzwi". Wzięło w niej aktywny udział 100 misjonarzy. Po jej zakończeniu przeprowadzono rekolekcje ewangelizacyjne dla wszystkich,

26 Por. R. Fisichella, „Carta al Equipo”.

27 Por. A. Navarro, Parroquia evangelizadora, 6. 
którzy wyrazili chęć uczestniczenia w nich. Po nich zostały stworzone małe wspólnoty, które spotykały się co tydzień, aby w ramach katechezy pogłębiać swoją wiarę. Ten nowy proces ewangelizacyjny przeniesiony na grunt parafii stał się początkiem $\mathrm{SINE}^{28}$.

\subsection{Parafia - naturalna przestrzeń dla SINE \\ 2.3.1. Współczesne wyzwania stojące przed parafią}

Zwołany na rok 2012 przez Benedykta XVI Synod Biskupów poświęcony nowej ewangelizacji postawił sobie za cel ocenę działalności pastoralnej Kościoła oraz rozeznanie dróg ewangelizacji w obliczu wyzwań, z którymi trzeba się obecnie zmierzyć. Ważnym zadaniem dla synodu było znalezienie odpowiedzi na liczne pytania dotyczące trudności w przekazywaniu żywej wiary we wspólnotach kościelnych $^{29}$.

Pytania te są jak najbardziej aktualne w kontekście instytucji, jakimi są parafie. Stanowią one spore wyzwanie dla współczesnego Kościoła, zwłaszcza z uwagi na narastający proces, w których ludzie coraz mniej utożsamiają się z określonym i niezmiennym środowiskiem. Oznacza to praktyczną niemożność dotarcia do wszystkich i zapewnienia im możliwości wzrostu duchowego. Szczególnie mocno jest to zauważalne w środowisku miejskim. Przynależność do parafii ma tam coraz bardziej relatywne znaczenie, na co wpływa widoczna migracja ludzka. Jest też rosnąca grupa ludzi, którzy pomimo formalnej i terytorialnej przynależności do jakiejś parafii wybierają z jakichś powodów inną. Jeśli dodamy do tego coraz bardziej zauważalny brak księży, panorama robi się dość ponura ${ }^{30}$.

Trzeba przyznać, że życie parafii w wymiarze zasadniczym często ogranicza się do aspektu kultycznego. Z jednej strony mamy w niej do czynienia ze swego rodzaju duszpasterstwem elit. Jest ono skierowane do znikomego odsetka tych, którzy pojawiają się w kościele $\mathrm{w}$ miarę regularnie. Wielu z nich jest też zaangażowanych w jakiś

28 Por. tamże.

29 Por. R.D. Witherup, Saint Paul, 9.

30 Por. Kongregacja ds. Duchowieństwa, Nawrócenie Duszpasterskie, 8-9; A. Navarro, Parroquia evangelizadora, 40. 
ruch czy stowarzyszenie. Jednak zasadniczo w takiej parafii istnieje przede wszystkim duszpasterstwo masowe, które zajmuje duszpasterzom większą część czasu i ogranicza się do administrowania sakramentów - chrztów, mszy św., małżeństw, namaszczeń chorych czy innych. W dużej mierze o sakramenty te proszą osoby, które jednocześnie nie są zainteresowane pogłębieniem swojej więzi ze wspólnotą. Parafie traktują jak stację obsługową ${ }^{31}$.

Jak zauważa ks. Alfonso Navarro, inicjator SINE, zdecydowana większość parafii nie ma żadnego planu duszpasterskiego, a tym bardziej takiego, który poważnie traktowałby wyzwanie ewangelizacji $^{32}$. Brak zdolności do podejmowania poważnych wyzwań $\mathrm{w}$ ramach funkcjonowania parafii może w wielu wiernych budzić poczucie frustracji i rodzić przekonanie, że nie mają już one racji bytu, że może na ich miejsce powinno się tworzyć małe wspólnoty, dogodniejsze i sprawniejsze. Niemniej jednak, jak przypomina Jan Paweł II, parafia pozostaje miejscem, z którym chrześcijanie, nawet niepraktykujący, złączeni są ścisłymi więzami. Cała zaś mądrość polega na tym, aby parafiom dać stosowniejsze struktury i wlać w nie nowego ducha ${ }^{33}$. Jeszcze dobitniej wyraził to papież Franciszek. Snując refleksję w kontekście konieczności duszpasterskiego nawrócenia, napisał on, że w tym względzie dużo zależy od otwartości i misyjnej kreatywności duszpasterzy i wspólnoty ${ }^{34}$. To w ich gestii jest to, czy wskazane przez Franciszka obszary dla nowej ewangelizacji - duszpasterstwo zwyczajne, środowisko osób ochrzczonych, ale nieżyjących według wymogów chrztu św., oraz wyjście do tych, co Chrystusa jeszcze nie znają - zostaną zagospodarowane ${ }^{35}$.

\subsubsection{SINE jako model pastoralny dla parafii}

Parafia jest oczywistym kontekstem, bez którego nie można zrozumieć SINE. Jest ona bowiem przestrzenią, gdzie jej członkowie powinni odnajdywać zachętę i przestrzeń do formowania oraz

31 Por. Kongregacja ds. Duchowieństwa, Nawrócenie Duszpasterskie, 17;

A. Navarro, Parroquia evangelizadora, 41-43.

32 Por. tamże.

33 Por. Jan Paweł II, Catechesi tradendae, 67.

34 Por. Franciszek, Evangelii gaudium, 28.

35 Por. tamże, 14. 
angażować się $\mathrm{w}$ ewangelizację ${ }^{36}$. Jest ona naturalnym miejscem dla realizacji Systemu zarówno w wymiarze głoszenia kerygmatu, jak i prowadzenia katechezy. SINE jest planem pastoralnym mającym za zadanie objęcie wszystkich, którzy zamieszkują jej terytorium ${ }^{37}$. Istotny jest w nim rzeczywisty i efektywny powrót do misyjnego wymiaru Kościoła poprzez podjęcie wysiłku, z jednej strony aby wszyscy ochrzczeni na nowo odkryli wartość swojego chrztu, a z drugiej strony aby dotrzeć z systematyczną ewangelizacją do tych najbardziej oddalonych, do peryferii ${ }^{38}$. SINE można określić jako podstawowy model pastoralny, którego celem jest taka przemiana parafii, aby poprzez styl swojego życia, aspekt wspólnotowy i podejmowane działania wypełniała ona zasadniczą misję Kościoła, jaką jest ewangelizacja. Należy jasno zaznaczyć, że nie jest to żaden nowy ruch w Kościele ani żadna nowa organizacja, stowarzyszenie czy szkoła w ramach duszpasterstwa specjalnego.

Można zatem powiedzieć, że jest to:

- $\quad$ podstawowy model pastoralny jednoczący wizję i konkretny schemat pastoralny;

- $\quad$ model na tyle prosty, że odwołuje się jedynie do fundamentalnej misji Kościoła, która jest możliwa do zrealizowania w ramach zwykłych duszpasterskich struktur parafii;

- $\quad$ model realizowany w imieniu samego Kościoła, a nie żadnego ruchu czy kościelnego stowarzyszenia;

- $\quad$ model, którego promotorami, animatorami i prowadzącymi powinni być: biskup (jeśli podejmuje się wcielenia go w swojej diecezji) i proboszcz w swojej parafii ${ }^{39}$.

SINE to plan, którego podstawową wizją jest parafia jako wspólnota ewangelizacyjna. Celem, jaki stawiają sobie duszpasterze, jest powiększać liczbę wiernych, którzy doświadczywszy rekolekcji ewangelizacyjnych, tworzą małe wspólnoty i angażują się na różnych płaszczyznach w życie parafii. Jest to proces animowany przez proboszcza i współpracujących z nim świeckich. Należy przy tym

\footnotetext{
36 Por. tamże, 28; Kongregacja ds. Duchowieństwa, Nawrócenie Duszpasterskie, 12.

37 Por. A. Navarro, Parroquia evangelizadora, 39.

38 Por. „Qué es el SINE? Presentación de SINE”.

39 Por. A. Navarro, Parroquia evangelizadora, 48-49.
} 
dodać, że w żaden sposób nie zaniedbuje się tych aktywności duszpasterskich, które odpowiadają na potrzeby wiernych niezainteresowanych pogłębieniem swojego zaangażowania w życie parafii ${ }^{40}$.

\subsection{Etapy urzeczywistniania SINE}

SINE jest procesem o charakterze ewangelizacyjnym z elementami i etapami jasno zdefiniowanymi, które zostały wypracowane na podstawie doświadczeń duszpasterskich Kościoła w Ameryce Łacińskiej $^{41}$. Pierwszym krokiem dynamiki systemu jest tzw. dom przygotowania i weryfikacji (casa de preparación $i$ verificación ${ }^{42}$ ), mający na celu zebranie tych, którzy na przykład podczas misji czy w jakikolwiek inny sposób zostali niejako ,poruszeni” i są zainteresowani dalszym pogłębieniem swojego chrześcijańskiego doświadczenia. Jest to czas na przygotowanie ich do rekolekcji ewangelizacyjnych (retiro de evangelización), które są kolejnym krokiem ${ }^{43}$. Stanowią one priorytet duszpasterski i bazę dla całego chrześcijańskiego życia. Rekolekcje te są bowiem przestrzenią dla pierwszego głoszenia czy - inaczej mówiąc-przepowiadania kerygmatu. W zależności od okoliczności można je przeprowadzić w trybie tygodniowym (co tydzień jeden temat), intensywnym (zaczynają się w czwartek wieczorem, a kończą w niedzielę), całodniowym (dwa intensywne dni - sobota i niedziela) lub tzw. kombinowanym (pierwszy blok tematów jest rozłożony na tygodnie, a drugi realizuje się w ciągu jednego dnia) ${ }^{44}$. Wraz z tymi rekolekcjami kończy się pierwszy etap - kerygmat.

Kolejnym krokiem jest tzw. duszpasterstwo kontynuacji (pastoral de seguimiento ${ }^{45}$ ). Wierni, którzy brali udział $\mathrm{w}$ rekolekcjach

40 Por. tamże, 43-44.

41 Aby zapoznać się ze szczegółowymi opisami etapów realizacji SINE, można sięgnąć po $A B C$ del SINE.

42 Czasami mogą pojawiać się inne nazwy tego etapu: casa de reunión czy semillero. Może też ulegać modyfikacjom zakres tematów i czas jego trwania. Por. Diócesis de Neiva, Paso uno.

43 Por. A. Navarro, Instructivo de Evangelización, 3.

44 Por. tamże, 5-15.

45 Czasami występują inne nazwy, np. casa de koinonía; por. Diócesis de Neiva, Paso uno. 
ewangelizacyjnych, zostają zaproszeni do stworzenia małych wspólnot. Początkowy okres po zakończeniu rekolekcji jest jednak specyficzny. Nie jest to już czas na głoszenie kerygmatu, ale też jeszcze nie jest to odpowiedni moment na wejście w rytm katechezy. Określa się go raczej jako zachętę do dalszego uczestniczenia i do pozostania na drodze ucznia i misjonarza (permanecer y perseverar). Trwa on około czterech miesięcy. W czasie cotygodniowych spotkań prezentuje się i wyjaśnia tematy związane z lekturą Biblii, z niektórymi aspektami modlitwy osobistej i wspólnotowej, doniosłość kwestii wspólnoty i łączności z parafią oraz konieczność sakramentów w życiu chrześcijanina, szczególnie Eucharystii. Wyjaśnia się również, na czym polega plan pastoralny realizowany w parafii. Kończąc ten okres, uczestnicy powinni rozumieć znaczenie czterech elementów: małych wspólnot, katechezy, cotygodniowego zaangażowania apostolskiego oraz finansowego wsparcia dla duszpasterstwa i ewangelizacji prowadzonej przez parafię ${ }^{46}$. Wieńczą go tzw. rekolekcje eucharystyczne (retiro de Eucaristía ${ }^{47}$ ). Powinny na nich zostać zaprezentowane tematy poświęcone wejściu w tajemnicę Eucharystii ${ }^{48}$. Wraz z tymi rekolekcjami kończy się drugi etap - koinonía.

Trzeci etap jest określany jako wspólnota (comunidad). Sformowane małe wspólnoty są środowiskami, w których wierni wzrastają w wierze i uczestniczą w systematycznej katechezie. Ich członkowie nie ograniczają się jednak do swoich wspólnot, ale ofiarowują swój czas, aby w ramach swojej posługi misyjnej kontynuować misję w parafii, odwiedzając wyznaczone domy i rodziny. Angażują się również w posługę duszpasterską w parafii według otrzymanych i rozpoznanych charyzmatów ${ }^{49}$.

46 Por. A. Navarro, Pastoral de seguimiento, 3-4.

${ }^{47}$ Czasami występują inne nazwy - np. retiro de koinonía. Por. Diócesis de Neiva, Paso uno.

48 Por. A. Navarro, Pastoral de seguimiento, 76-102.

49 Por. tenże, Parroquia evangelizadora, 178-280. 


\title{
Zakończenie
}

Doświadczenia ostatnich dziesięcioleci pokazują wyraźnie, że Ameryka Łacińska zaczyna być inspiracją dla całego Kościoła powszechnego. Tam też w jakiejś mierze rozstrzyga się jego przyszłość ${ }^{50}$. Wyraźnym tego przykładem jest inspirująca rola ostatnich konferencji Rady Biskupów Ameryki Łacińskiej (CELAM) - szczególnie tych z Puebla, Santo Domingo i Aparecidy. Nie bez znaczenia jest tu rola Franciszka - pierwszego papieża z tego kontynentu. To on przynagla współczesny Kościół, aby wraz ze wszystkim swoimi strukturami, również diecezjalnymi i parafialnymi, przyjął ukierunkowanie misyjne. Wszystkie jego działania mają być podporządkowane zadaniu głoszenia Ewangelii współczesnemu człowiekowi. Oznacza to konieczność pastoralnego nawrócenia. Tylko w taki sposób duszpasterstwo przestanie być administrowaniem, a stanie się środowiskiem nieustannej misji ${ }^{51}$.

Wypracowany w Meksyku Integralny System Nowej Ewangelizacji (SINE) jest konkretnym programem duszpasterskim w duchu nowej ewangelizacji, który sprawdza się nie tylko w Ameryce Łacińskiej. W ostatnich latach stał się również przedmiotem ożywionego zainteresowania chociażby Episkopatu Korei Południowej. Autorzy tego artykułu są przekonani, że byłby on również ciekawą i atrakcyjną odpowiedzą na aktualne wyzwania stojące przed duszpasterstwem parafialnym w Polsce. Nikt nie ma już przecież wątpliwości, że Kościół w naszym kraju coraz mocniej odczuwa przynaglenie do porzucenia sposobów działania należących do przeszłości i odważnego stawienia czoła wyzwaniom współczesności.

\section{The Integral System for the New Evangelization as a Response to the Call of the Church in Latin America for a New Evangelization}

\begin{abstract}
Since the Second Vatican Council, the awareness of the challenges to evangelization that the Church is facing has been growing stronger. Beginning with the Third Latin American Episcopal Council (CELAM) in Puebla in 1979, the call to seek new forms and methods for evangelization in a rapidly changing reality started to be
\end{abstract}

50 Por. A. Ivereigh, Prorok, 349.

51 Por. Evangelii gaudium, 27-30. 
called "new evangelization". Thanks to St. John Paul II, this term has permanently stayed in the consciousness of the universal Church.

The pontificate of Pope Francis supports Latin America in continuing its inspirational role in "new evangelization". According to the authors, an interesting pastoral initiative of new evangelization is the Integral System of New Evangelization (SINE - Sistema Integral de la Nueva Evangelización), initiated in Mexico and successfully implemented in many regions of the world, where it has become an official pastoral program for numerous dioceses and parishes. Recognizing the situation of the Church in Poland and the evangelical anxiety of many priests, this system is an interesting solution which - if creatively developed - can transform a traditionally run parish into a vibrant community of communities.

Keywords: Integral System for the New Evangelization, new evangelization, parish, pastoral model, SINE

\section{Bibliografia}

ABC del SINE, Pereira (Colombia) 2014.

Andrade Ponte, P., „La catequesis latinoamericana al impulse de Medellín y Puebla", Medellín 58-59 (1989), 133-151.

Berryman, P., „What happened at Puebla”, w: Church and politics in Latin America, D.H. Levine (red.), Beverly Hills-London 1979-1980.

Conferencia Episcopal Latinoamericana, ,Documento final de la III Conferencia Episcopal Latinoamericana (27 de enero al 12 de febrero de 1979) [Puebla]", w: Documentos de Santo Domingo, Puebla, Medellín y Río de Janeiro, Buenos Aires 2008.

Conferencia Episcopal Latinoamericana, "Documento final de la IV Conferencia Episcopal Latinoamericana (12-28 de octubre de 1992) [Santo Domingo]", w: Documentos de Santo Domingo, Puebla, Medellín y Río de Janeiro, Buenos Aires 2008.

Diócesis de Neiva (Colombia), Paso uno: kerigma, http://www.diocesisdeneiva. org/sine/paso-uno-kerigma (dostęp 16.02.2019).

Equipo de Reflexión Teológica Pastoral de CELAM, Reflexión sobre Puebla, Bogotá 1980.

Fernández, M., Kaproń, K., „Nie możemy biernie czekać - rozmowa”, Więź 56 (2013) nr 4.

Fisichella, R., „Carta al Equipo de SINE del 1 de abril de 2014”, http://www. sinebrasil.com.br/erapido/arquivos/midia/548804b76209f8d440f5880ff673 34d4.pdf (dostęp 15.02.2019).

Fisichella, R., La nuova evangelizzazione. Una sfida per uscire dall'indifferenza, Milano 2011.

Franciszek, Adhortacja apostolska Evangelii gaudium, Częstochowa 2014. 
Galli, C.M., „Dones de la Iglesia latinoamericana a la nueva evangelización. Novedades de «Evangelii nuntiandi» y Puebla hasta Aparecida y el Sínodo 2012”, Gregorianum 93 (2012), 593-620.

Gonzales Dorado, A., „La Nueva Evangelización. Genesis y líneas de un proyecto misionero", w: A. Gonzales Dorado (red.), La Nueva Evangelización. Genesis y lineas de un proyecto misionero, Bogotá 1990.

Hajduk, R., Ewangelia na forum świata. Od apologetyki do marketingu narracyjnego, Kraków 2013.

Ivereigh, A., Prorok. Biografia Franciszka, papieża radykalnego, Bytom 2015. Jan Paweł II, Adhortacja apostolska Catechesi tradendae, Kielce 1996.

Jan Paweł II, Adhortacja apostolska Ecclesia in America, Rzym 1999.

Jan Paweł II, Discurso en la inauguración de la III Conferencia General del Episcopado Latinoamericano, Puebla, 28 de enero de 1979, http:// w2.vatican.va/content/john-paul-ii/es/speeches/1979/january/documents/hf jp-ii_spe_19790128_messico-puebla-episc-latam.html (dostęp 20.10.2020).

Jan Paweł II, „Przemówienie do Konferencji Episkopatów Ameryki Łacińskiej (CELAM) w katedrze w Port-au-Prince", Haiti, 9.03.1983, L'Osservatore Romano (wyd. pol.) 3 (1983) nr 4.

Jiménez Carvajal, J., „Las cuatro conferencias generales: Río, Medellín, Puebla, Santo Domingo. El camino recorrido", Medellín 30 (2004), 177-218.

Kelly, T., When the Gospel grows feet. An ecclesiology in context, Collegeville (MN) 2013.

Kongregacja ds. Duchowieństwa, Instrukcja Nawrócenie duszpasterskie wspólnoty parafialnej w stużbie misji ewangelizacyjnej Kościoła, Wrocław 2020.

Kongregacja ds. Instytutów Życia Konsekrowanego i Stowarzyszeń Życia Apostolskiego, Rozpoznawajcie. Do osób konsekrowanych podązających szlakiem znaków Bożych, Warszawa 2014.

Leal, C., „La noción de justicia en la Gaudium et spes”, Teología y Vida 54 (2013), 181-204.

Marchesi, G., „Puebla y la teología de la liberación”, Documentación CELAM (1981) nr 28.

Navarro, A., Instructivo de Evangelización. Cómo dar el retiro de evangelización? Instructivo \# 4, México [b.r.].

Navarro, A., Parroquia evangelizadora. Sistema Integral de la Nueva Evangelización, México 1994.

Navarro, A., Pastoral de seguimiento. Discípulos misioneros, México 2014.

Paweł VI, Adhortacja Evangelii nuntiandi (8 grudnia 1975), Wrocław 2001.

Peterson, A., Vasquez M., „The New Evangelization in Latin America Perspective", Cross Current 48 (1998), 311-329.

Quarracino, A., „El Concilio, Medellín, Puebla”, Revista Teológica Límense 18 (1984), 35-46. 
"Qué es el SINE? Presentación de SINE", https://www.slideshare.net/angelmiguelha/presentacion-sine (dostęp 17.02.2019).

Ruiz Arenas, J.O., „Dokument z Aparecidy a wskazówki pastoralne Papieża Franciszka", http://nowaewangelizacja.org/abp-jose-octavio-ruiz-arenas-dokument-z-aparecidy-a-wskazowki-pastoralne-papieza-franciszka/ (dostęp 10.10.2015)

Sentido eclesial en el origen del SINE, https://sinecentral.org/461-2/ (dostęp 20.10.2020).

Sobór Watykański II, Konstytucja duszpasterska o Kościele w świecie współczesnym Gaudium et spes (7 grudnia 1965), w: Sobór Watykański II, Konstytucje, Dekrety, Deklaracje, Poznań 2002.

Sobór Watykański II, Konstytucja dogmatyczna o Kościele Lumen gentium (21 listopada 1964), w: Sobór Watykański II, Konstytucje, Dekrety, Deklaracje, Poznań 2002.

Synod Biskupów, XIII Zwyczajne Zgromadzenie Ogólne, Orędzie do ludu Bożego, „L'Osservatore Romano” (wyd. pol.) 32 (2012) nr 23.

Witherup, R.D., Saint Paul and the New Evangelization, Collegeville (MN) 2013. 